\title{
Indonesian Digital Natives
}

\section{ICT Usage Pattern Study across Different Age Groups}

\author{
Neila Ramdhani and Wisnu Wiradhany \\ Universitas Gadjah Mada
}

\begin{abstract}
Since its first appearance on early 2000's at the U.S, the idea that a new generation of students called digital natives or net generation has entered the world has been widely discussed by parents and educators alike. It is said that this generation think, socialize, and act differently; and they will alter roles and regulation of work and educational institutes. Now, at the second decade of the 21 st century, Indonesia has to ready herself to meet this new generation. In this paper, we compared information and technology (ICT) access, activities within ICT, investment on ICT, and attitude towards ICT between five hundred Indonesian in three different groups: those who born before the 1980s; those who born between 1980s to 1989's, and those who born after the 1990s by ANOVA. We found that there were no difference on information and technology (ICT) access, activities, investment on ICT, and attitude towards ICT between the groups.
\end{abstract}

Keywords: ICT, Internet, Digital Natives.

\section{Introduction}

Since its emergence in the late 1970s, the internet has growth rapidly and change people's way of life [13]. At the 1980s, electronic mail has complimented face to face communication and correspondence communication. World Wide Web (web browser tool) made its debut in 1991, followed by the emergence with browser some time afterwards. At the end of the 1990s, search engines, portals, and e-commerce started to emerge. These innovations in the field of information technology are increasing at the 2000'swhen social networking sites and blogs were launched. In late 2008, music and video are integrated into the network via iTunes and YouTube [13].

Internet have changed the way people interact by eliminating physical boundaries and changing the way people manipulate the external world by opening a range of possibilities in using collaborative media. In this environment a generation who no longer intimidated by the presence of new digital technologies was born. They are able to use the technology better than their parent. Tapscott [17] extremely states that this digital generation is breathing with the technology.

In the United States, this generation is made up of citizens who were born after 1980s. They spent their teenage years in the late 1990s, where the Internet and personal computers can be found in every private home. This digital generation is 
known also known as net generation [17] or digital natives [13, 14]. As a generation who are familiar with technology, digital natives have different characteristics than the previous generation. Through nGenera survey from 6,000 digital generations, Tapscott [17] summarizes these differences into eight main characteristics that reduced further to four characteristics by Leung [9] as follows:

1. Global orientation and emotionally uninhibited: this generation finds it easier to share their thoughts online to everyone they can find, protected by the anonymous nature of the internet.

2. Right to information and learning: this generation beliefs in equal opportunity and freedom of expressions of opinions. Keeping up with newest information helps them to ensure their employability

3. Technological savvy: this generation has a keen interest not only in new technologies, but also how they work.

4. Preoccupied with maturity and adulthood: this generation expect to be treated as an adult, no matter how old they are.

Digital natives also use technology in different ways from their previous generations. As the generation that was born and grew up with technology, they are able to use technology in a more diverse and more efficient way than their previous generation who dealt with technology in older age. A survey from Kvavik [8] shows how digital natives use technologies for wide arrays of activities, from productive activities such as writing documents and sending e-mails to recreational activities such as random browsing and chatting with friends and colleagues. Their activities also varied from using basic technology such as word processing and presentation to using advanced technologies such as 3D Graphics and web design. These characteristics and competencies are different from previous generations in which work and entertainment are more limited, and most of the work can takes a long time in the settlement process.

If Prensky [14] calls this digital generation "digital natives," the previous generation is called with a digital immigrant. The digital natives born and raised in the technology, but digital immigrants born before the technology was rampant. The digital natives became familiar with the technology at their adolescence, while the digital immigrant met these technologies in adulthood. With these different environment, comes different characteristics between the generations.

In the context of work for example, it can already be found digital natives who are smarter than the digital immigrants on operating software. The digital natives were able to find the information more quickly, and could complete certain work more efficiently with the help of the internet [13]. In the context of education, students were found correcting information from their teachers, with the help of information found in the internet by smart phones [17].

In Indonesia, the internet were started to use widely by the end of 1996 [4]. In contrast to the characteristics of Internet used in the United States, where each house has its own connection, internet connection in Indonesia can be find communally in internet cafes, or commonly known as warnet $[4,10]$ which has different characteristics from private pay system 
Although having different way to access the Internet, interestingly Indonesian people have similar pattern in terms of the diversity of activities done online with Western society. Such similarity depicted in a survey conducted by Wiradhany [18], which shown that the Indonesian people are familiar with common functions such as internet browsing (surfing), chat room, and e-mail. Set of studies summarized by Hill and Sen [5] also showed that in general, Indonesia's young generation is using the internet. Campus ranks third as a place to access the internet; Undergraduate and High School Students ranked first and second levels of internet users; and students and youth as the two largest Internet user groups [5].

The goal of this paper is to identify ICT usage pattern of young internet user of Indonesia. From the previous findings, it is expected that it will show similar pattern with findings from Western Countries. Secondly, by comparing young internet users to their previous generation, this paper also wants to look up how much differently young internet user use technology compared to their previous generation.

The results of this research can enrich the discourse on the impact of technology to the people of Indonesia, since a similar study has not been done much. Psychological discourse of the digital generation can be widely diverse, ranging from discussion of internet addiction [19], the use of technology in the learning process [12], the dynamics of interaction patterns in the family [16], organizations that can maximize the potential of this generation [17], and various other areas of Psychology in contact with the digital generation. The results of this study can be used as a basis for the study of digital natives in Indonesia in the future.

\section{Methods}

There are three variables in this study: age, ICT-related behavior, and ICT-related attitudes. Age were grouped by those who were born in the 1970s and before, those who born between the 1980 to the 1989, and those who born after 1990s. ICT-related behavior was described by (1) accessibility and gadgets owned (2) activities within the internet and gadgets and (3) the investment for technologies monthly.

The data in this study were obtained through a survey on technology ownership, internet access, use of internet, mobile phone use, computer use, use of game consoles, and attitudinal scales of the digital generation. Items in the general survey were developed based on Wiradhany [18] findings, while the scale of the digital generation attributes were adopted from a similar scale made by Leung [9].The digital generation attitudinal scale consists of four dimensions, namely (1) the right to information, (2) unhibition in the net, (3) technological savvy, and (4) adulthood and confident. The overall scale of the attribute consists of 24 items with an internal consistency of each of the items ranged from 0.25 to 0.47 and Cronbach Alpha reliability of 0.82 .

Ninety-nine percent of respondents (304 people) write their gender. Of that quantity, $56.4 \%$ (172 people) of respondents are female, while the remainders (132 people) are men. They were born in the 1970s, 1980s, and 1990s. The digital generation was assumed born in 1990s. Generation born in the two decades prior is used as a comparison to see the contrast between the use of technology between digital generation and previous generations. 
Table 1. Age of Respondents

\begin{tabular}{lr}
\hline \multicolumn{1}{c}{ Decades } & Respondents \\
\hline$<1979$ & 7 \\
\hline $1980-1989$ & 83 \\
\hline$\geq 1990$ & 199 \\
\hline Total & 289 \\
\hline
\end{tabular}

Ninety-four percent of the respondents (289) wrote their date of birth. The mean of respondent's age was 21.96 with $4.26 \mathrm{SD}$. The youngest respondent is 13 years old and the oldest respondent is 60 years old by 2012 .

\section{$3 \quad$ Result}

Survey analyses were divided into two parts, namely (A) mapping of the various technologies used and (B) attitude toward technology. In the first part, the results of this survey will be presented to the (1) Variety of technologies used across generation, (2) the activities within Internet, and (3) The amount of the investments made to access the technology.

\subsection{Mapping of the Various Technologies Used}

1. Variety of technologies used across the generations

Figure 1 shows the difference in technology products ownership between digital generation and the previous generation. For those who were born in the 1970s and 1980s, USB flash drive (100\% and 94\%) are the most widely owned product, followed by mobile phones (85.7\% and 92.8\%), and Internet access/laptops (71.4\% and $90.4 \%)$. In the group that was born in 1990s, three top technologies are a cell phone (95\%), laptops $(92.5 \%)$, and Internet access $(90.5 \%)$.

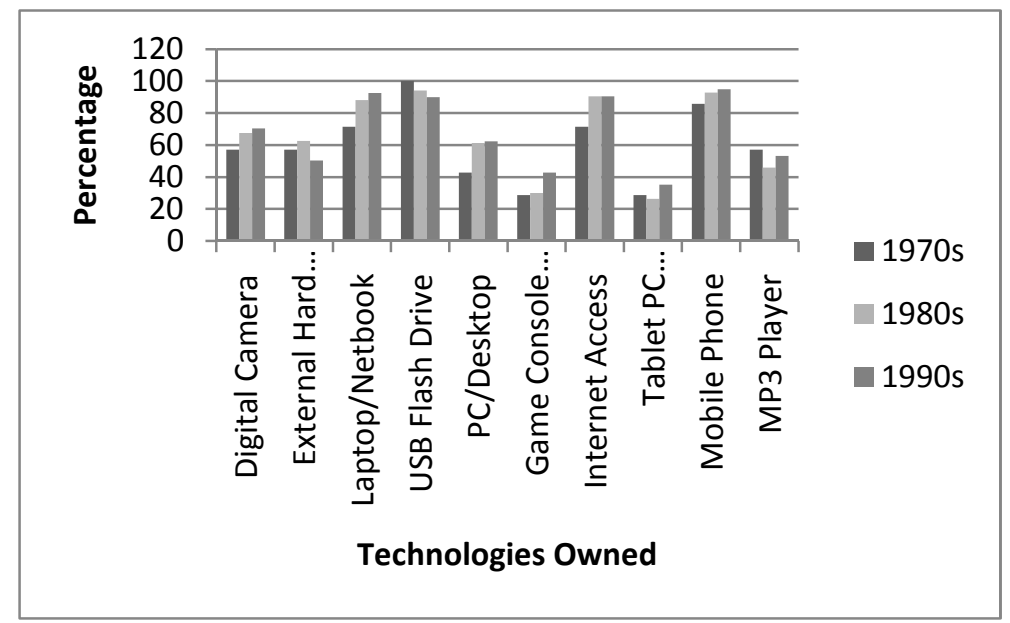

Fig. 1. Technology Owned across Generation 
Data management (flash drive and laptops) and communication (mobile phone and internet) are agreed by whole groups as essentials technologies. High usage of laptops than PC, and mobile phone also shows how important mobility is. Our data from internet access also shows that internet hotspot, HSDPA modem, and mobile internet plays significant role for people to access internet.

\section{Activities within Technologies}

Efforts to understand the intensity and engagement of digital generation with technology were done by comparing activities within technology with the previous generation. Activities compared included: activities on mobile phone, PC/laptop, and internet. While all groups use mobile phone to send text and make phone calls, respondent born at the 1990s also used them for social networking and chat. If mobile phone is used mainly for organizing schedule, computer is mainly used to work on documents related to schoolwork or office.

All groups of respondents used computer more to access the Internet $(100 \%$, $96.4 \%$, and 94\%, respectively). Figure 2 shows that all groups go online mainly for checking their e-mails, browsing, downloading data, and social networking. It is interesting that younger people tend to do more recreational browsing while older generation browses for task-related activity.

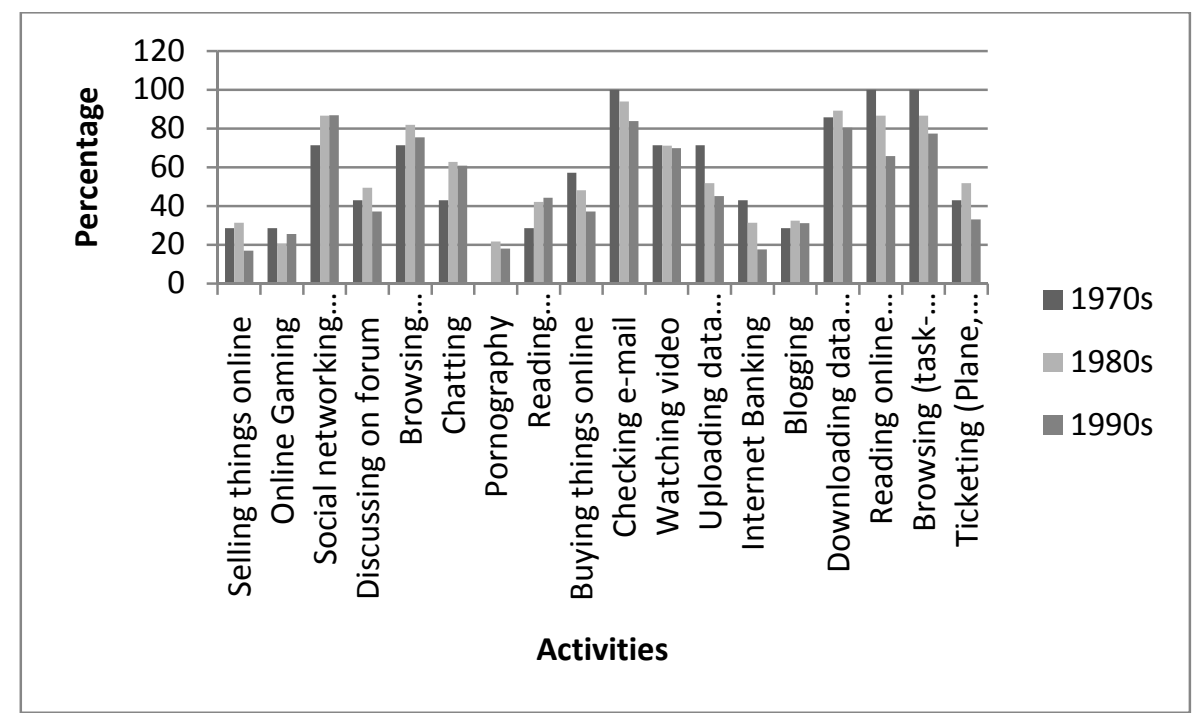

Fig. 2. Online Activities

\section{Investing on Information Technology}

Access to information technology in Indonesia is still a serious problem for its users. However, the price is often defeated by necessity. For the digital generation, information technology has become imperative. This survey shows that respondents born 1980 s are the most likely group to spend money on the Internet than respondents born 
1990s and 1970s. On average, respondents who were born in the 1970s to spend Rp. $57,857.14$ per week for a mobile telephone, respondents were born in 1980s for Rp. 43,939.76 - and 1990s Rp. 40,055.13.

Another interesting investment observed to understand the information technologyrelated behavior is in terms of time. The data obtained showed that the range of time spent by respondents from each generation tend to be different. The respondents were born in the 1970s spent most of the time with their cell phones for noncommunication activities such as listening to a song and taking pictures (31.67 minutes) and check e-mail. Those born in the 1980s spent more time on noncommunication activities (25.38 minutes) and also for chatting (22.06 minutes). Diversity is becoming increasingly different on respondents born in 1990s because they mostly use his mobile phone to chat (56.42 minutes) and send short messages (33.10 minutes).

Chatting is a synchronous communication activity between two or more users of information technology. This mobile phones facilitated communication is widely used by the digital generation. Compared with communication via e-mail, chat allowed users of Internet technology to obtain near real-time response. Chat usage depicts speed as one of the characteristics of the digital generation.Speed is required by the digital generation not only in terms of obtaining the response, but also in fulfilling their needs of information. Browsing or surfing the internet is an activity done to meet these needs.

For activities within computer, the most time-consuming activities are web design, browsing, using Ms. Office, and offline gaming. No perceived differences between groups were found here. But interestingly, when asked about online activities, we found that respondents born on 1970s spent most of their time online for gaming and chat, while younger generation tend to do more browsing for task-related activities. Activities done to develop relationships that have been established through chat and online gaming seem to be two examples of activities done by1970s generation. Prensky [14] refer to this generation who born on the1970s as digital immigrants because the internet was present at the time they are adult. They are required to live and conform to the pattern of life in the era of digital technology. They treat technology as a tool to facilitate the achievement of their goals and enrich the quality of communication that had been established.

In the country with a collectivist culture, social life is managed by growing need among individuals and another. Greeting each other is not just lip service but rather form of fulfillment of needs. Media that facilitates the echo-reply brief communication like chat become a very popular choice in Indonesia. Ramdhani [15] found that in the Paperless Office communication media, social topic is the most frequent topic discussed among university lecturers.

Different trend is shown by the generation born at the 1990s. They spent more time browsing for task-related activities. Internet technology already exist at the time of this generation hit adolescence, so doing job/school related activities are more important for them. 


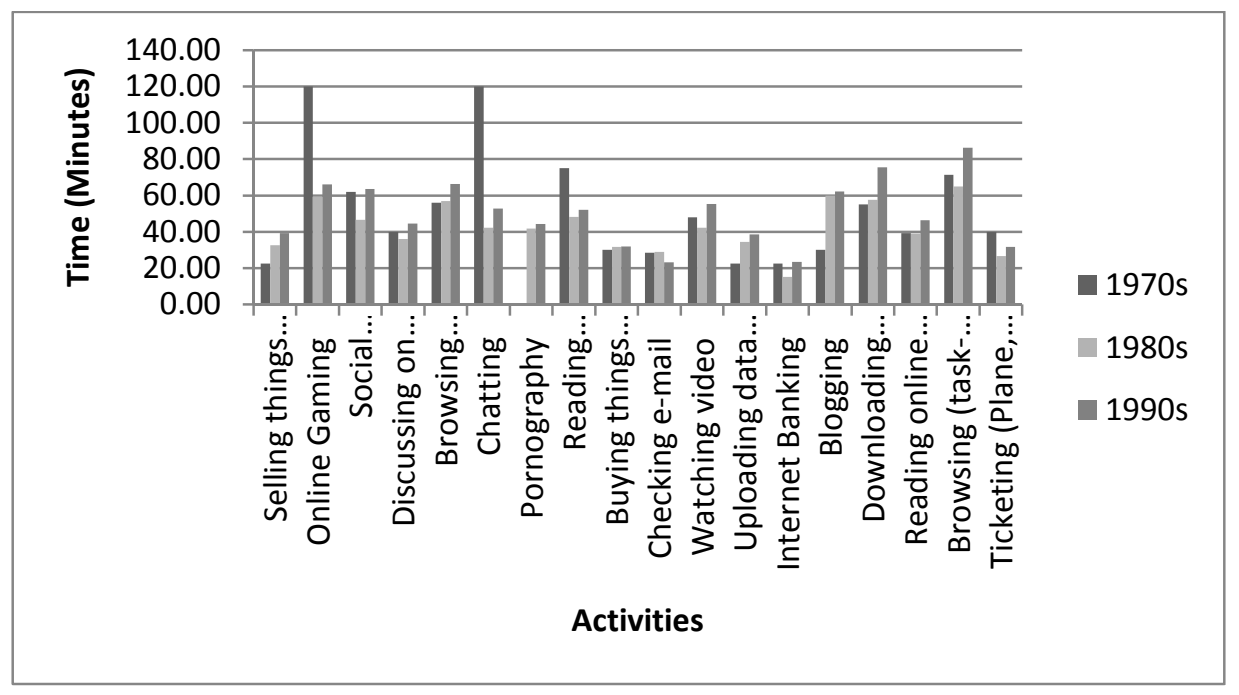

Fig. 3. Time Spent Online

\subsection{Attitude towards Technology}

Utilization of various technologies for life is determined by the perception of how important each feature provided by these technologies. All generations put internet and mobile phones as the technology they need. The difference between them lies in the management of data. If the generation born 1970s requires a USB Flash Drive, those who were born in the 1990sand 1980s find laptops more important. There are at least three possibilities that could be used to understand this. First, laptop with various specification and prices can be easily found in market nowadays. Second, USB Flash drives can only be used for storing data, while laptop can be used for various purposes. Third, digital generation can utilize various features of the Internet to access their files (e.g. cloud storage), so that files can be accessed from anywhere without having to be burdened with the risks of the use of USB Flash Drive.

In addition to the popular range of technology, the survey also shows that the Game Console and tablet PCs including the iPad and the Galaxy tab is a technology that is considered less important than other technologies such as laptops and computers. This may be based on the assumption that console and PC games do not directly support productivity. However, Figure 4 also shows that music player is pretty much used by all three generation.

Four attributes of the digital generation [9] is elaborated by comparing the pattern of the four attributes among respondents who were born in the 1970s, 1980s, and 1990s. The data show that the distribution of scores of all respondent groups did not differ, with the exception of right to information. Younger people tend to demand higher right to information as the number of information stored online increases [13]. However, contrary to the assumption of net generation, those born in the year 1980s has a higher net-generation attributes average score (70.18) than those born at the 
1990s (68.79). The figure also shown that adulthood and confidence score has a positive correlation with age. This is expected because people tend to be more confident as they become older.

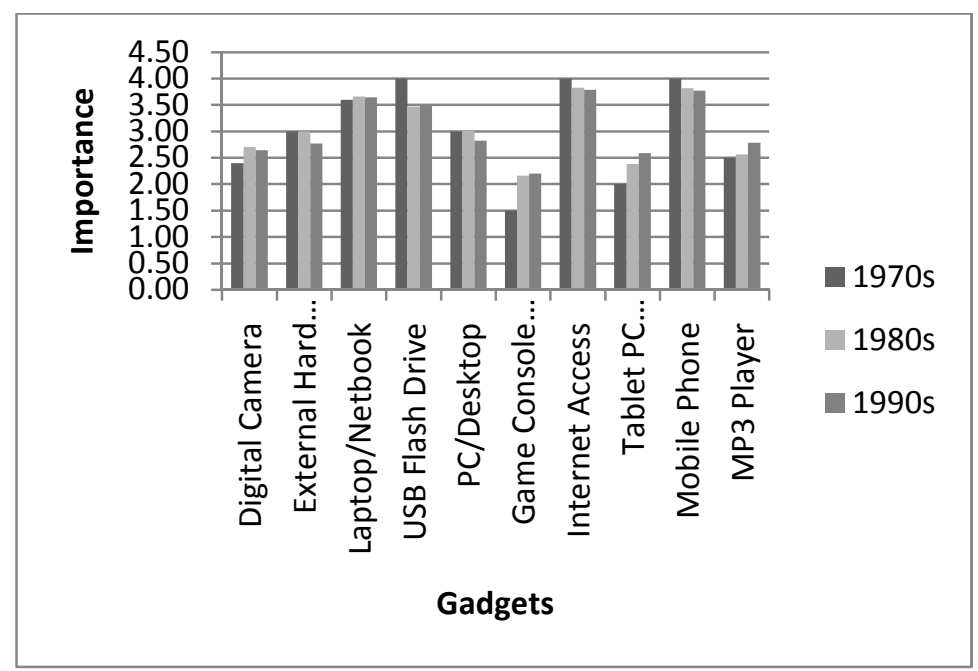

Fig. 4. Importance of Gadgets (1=Very Unimportant; 4=Very Important)

Finally, we weight and compare all of our data regarding the five attributes related to technology (access, activities, cost, time, and attitude) with each other. We then compute their differences using ANOVA.

Table 2. Net Generation Model Comparison ( $\mathrm{N}=289)$

\begin{tabular}{|c|c|c|c|c|c|c|}
\hline & & Access & Activity & Cost & $\begin{array}{l}\text { Time } \\
\text { Spent }\end{array}$ & Attitude \\
\hline \multirow[t]{4}{*}{ Total } & Mean & 3.260 & 3.372 & 3.264 & 3.272 & 2.876 \\
\hline & $\begin{array}{l}\text { Std. Devia- } \\
\text { tion }\end{array}$ & 1.186 & 0.842 & 2.836 & 2.513 & 0.428 \\
\hline & $\mathrm{F}$ & 0.961 & 0.874 & 1.476 & 0.357 & 0.086 \\
\hline & Sig.* & 0.384 & 0.418 & 0.230 & 0.700 & 0.917 \\
\hline
\end{tabular}

* Significant for $\mathrm{p}<0.05$.

From the comparison shown on table 5 it can be seen that there are no significant difference between access, activities, cost, time, and technology-related attitudes among those who were born in the 1970s, 1980s, and 1990s. This result is contrary to the first survey was done by the Americans. 


\section{Conclusion}

While showing certain characteristics of digital generation, this survey find that those assumed as digital generation in Indonesia show no different pattern in technological access, activity, cost, time spent, and attitude from their previous two generations. These results are in line with Carrier, Cheever, Rosen, Benitez, and Chang [1] who found that there were no significant multitasking behavior patterns as sign of digital generation across different age groups in the United States. Other surveys done in the U.K. [3, 11]; and Australia [2, 7] have also shown similar pattern. While reporting themselves as more engaged in using different kinds of technologies, those assumed as digital generation are too heterogeneous to be classified as a group: only a minority of them is truly technological savvy. Most of individual fall in this group are not more technologically illiterate than their previous generation.

However, results from this survey came from limited numbers of respondents. It seems that the digital generation of Indonesia behavioral patterns cannot be described with a limited number of respondents in the study. In addition, Indonesia also faced the inclusion of Internet technology. The responsiveness of inter-generational Internet users in Indonesia still needs to be studied further.

\section{References}

1. Carrier, L.M., Cheever, N.A., Rosen, L.D., Benitez, S., Chang, J.: Multitasking across generations: Multitasking choices and difficulty ratings in three generations of Americans. Computers in Human Behavior 25, 483-489 (2009)

2. Combes, B.: Generation Y: Are they really digital natives or more like digital refugees? Synergy 7(1), 31-40 (2009)

3. Helsper, E., Enyon, R.: Digital natives: Where is the evidence? British Educational Research Journal, 1-18 (2009)

4. Hill, D.T., Sen, K.: Wiring the warung to global gateways: The internet in Indonesia. Indonesia 63, 67-89 (1997)

5. Hill, D.T., Sen, K.: Internet in Indonesia's New Democracy. Routledge, London (2005)

6. Jones, C., Ramanau, R., Cross, S., Healing, G.: Net generation or Digital Natives: Is there a distinct new generation entering university? Computers \& Education 54(3), 722-732 (2010)

7. Kennedy, G., Krause, K., Judd, T., Churchward, A., Gray, K.: First year students' experiences with technology: Are they really digital natives? Preliminary Reports of Findings, Biomedical Multimedia Unit of University of Melbourne Research (2006)

8. Kvavik, R.B.: Convenience, Communications, and Control: How Students Use Technology. In: Oblinger, D., Oblinger, J. (eds.) Journal of Educating Net Generation. Educase (2005), http: / / www . educause.edu/educatingthenetgen/

9. Leung, L.: Net-Generation Attributes and Seductive Properties of the Internet as Predictors of Online Activities and Internet Addiction. Cyberpsychology \& Behavior 7(3), 333-348 (2004)

10. Lim, M.: Internet, Social Networks, and Reform in Indonesia. In: Couldry, N., Curran, J. (eds.) Contesting media power: Alternative media in a networked world. Rowman \& Littlefield, Maryland (2003) 
11. Margaryn, A., Littlejohn, A.: Are digital natives a myth or reality?: Students' use of technologies for learning. Computers \& Education 56(2), 1-30 (2008)

12. Oblinger, D., Oblinger, J.: Journal of Educating Net Generation. Educase (2005), http: / / www. educause. edu/educatingthenetgen/

13. Palfrey, J., Gasser, U.: Born Digital: Understanding the First Generation of Digital Natives. Basic Books, New York (2008)

14. Prensky, M.: Digital Natives Digital Immigrants. On the Horizon 9(5) (2001)

15. Ramdhani, N.: Komunikasi berbasis Paperless Office: Studi tentang PLO Psikologi UGM. Jurnal Psikologi (dalam proses penerbitan) (2012)

16. Rosen, L.D.: Me, MySpace, and I: Parenting the Net Generation. Palgrave-MacMillan, New York (2007)

17. Tapscott, D.: Grown Up Digital: How the Net Generation is changing Your World. McGraw-Hill, New York (2009)

18. Wiradhany, W.: Uji Validitas dan Reliabilitas Alat Ukur Trust pada Pengguna ECommerce di Indonesia. Skripsi, tidak diterbitkan. Universitas Katolik Indonesia Atma Jaya, Jakarta (2010)

19. Young, K.S.: Internet Addiction: The Emergence of a New Clinical Disorder. CyberPsychology and Behavior 1(3), 237-244 (1998) 